\title{
GASIFICATION MODEL AS A FACTOR IN SUSTAINABLE DEVELOPMENT OF RURAL AREAS
}

\author{
Oleg Chekmarev ${ }^{1}$, Doctor of economics/associate professor; Pavel Lukichev², Doctor of \\ economics/professor; Pavel Konev ${ }^{3}, \mathrm{PhD}$ in economics/ associate professor \\ ${ }^{1}$ Saint-Petersburg State Agrarian University, Russia; 'Balic State Technical University "VOENMEH", Russia; \\ ${ }^{3}$ Leningrad state University named after A. S. Pushkin, Russia
}

\begin{abstract}
Sustainable rural development implies balancing of economic, social and environmental factors affecting quality of life. Achieving sustainable development is impossible without ensuring access of rural communities to uninterrupted and cost-effective supply of energy. High-quality socio-economic infrastructure for rural areas implies constant physical and economic access of households to energy resources. The purpose of the study is to develop recommendations for economically and environmentally efficient energy supply to the rural population. To achieve this goal, the following tasks are solved. Firstly, the environmental and economic advantages of using gas as a source of energy supply to the rural population are revealed. Secondly, calculations and comparative analysis of various gas supply options are carried out to ensure sustainable development of rural areas. Thirdly, cost-effective gas supply options are substantiated, depending on the characteristics of the population distribution. The article examines comparative efficiency of connections of rural communities to sources of gas supply against other methods of energy supply in rural areas. The analysis is made for purposes of regional planning for building a sustainable energy supply system for rural communities and does not provide for studying use of gas by non-household customers. The analysis takes into account settlement patterns of rural communities, economic and environmental factors, as well as the risks of ensuring the uninterrupted supply of necessary energy resources. Comparative advantages and disadvantages of connections to distribution pipelines vs. use of gasholders are evaluated. The paper analyses one of the regions of the North-West Federal District of the Russian Federation.
\end{abstract}

Keywords: rural areas, sustainable development, access to gas supply, economic efficiency.

JEL code: R22, R29

\section{Introduction}

The level of access of communities to gas supply remains quite low in Russia. This is particularly the case for rural communities. For example, the level of access of communities to gas supply in rural Russia amounted to $59.4 \%$ as of 01/01/2019, while in 2005 it was $34.8 \%$. At the same time, the level of access of urban communities to gas was $71.4 \%$ at the beginning of 2018. In 2015, the level of connection to gas mains of towns in the Leningrad Region has amounted to $78.4 \%$, and in rural areas it has achieved $42.6 \%$ only (The five-year program, 2019). Consequently, there is a significant lag in these processes in rural areas and the pace of connecting communities in different regions is diverse at the background of the positive dynamics in the general level of connection to gas supply.

It is generally agreed that the household sector is one of the most important energy consumption sectors (Wang Z. et al., 2011). Percent in energy consumption on the housing sector was $26 \%$ in Japan, in the US - $25 \%$, in Canada - $24 \%$, at least $16 \%$ - in Finland, in the world as a whole $31 \%$ (Swan G., Ugursal V., 2008). It was shown that not all factors have equal important in determining the pattern and behaviour of household energy consumption for different areas due to differences in socio-economic settings, environmental factors, cultural factors as well as the average level of development in the area (Danlami A. H. et al., 2015).

General feasibility of using gas as a source of energy supply for households stems from its high enough environmental safety, versatility of use (for heating, electricity, hot water, cooking) and relatively low cost of supplying gas via pipelines. Negative factors limiting the possibility of using gas 
for energy supply of residential premises are the high cost of laying pipelines and arranging gas distribution infrastructure and increased hazard of explosion at gas supply facilities.

Regional authorities are actively involved in funding development of gas supply infrastructure. Budget constraints make it necessary to evaluate economic efficiency of various models of providing gas to households. The article explores alternative models for gas supply, such as supplying a gas pipeline with and use of liquefied hydrocarbon gases in households with installation of individual gasholders. Alternatives are analyzed from the point of view of comparative economic efficiency of their use for providing gas to rural communities with different density of settlement and degree of remoteness from gas mains. The issue of reliability of household gas supply system is consistent with the main elements of sustainable development. Among the latter we may emphasise support and development of rural areas potential and balancing between economic and environmental development goals (Chekmarev O. P., Konev P. A., 2018).

\section{Materials and methods}

Environmental friendliness of using gas for household energy supply has been confirmed by numerous studies (Aksyutin O. E. et al., 2017). Use of natural gas and LPG makes it possible to reduce emissions of pollutants and carbon dioxide multiply compared to other types of fuel, both at the production stage and at the stage of operation of energy supply facilities. Ensuring access of communities to gas supply is the most important element in maintaining ecological balance and it is demanded from the point of view of the goals of sustainable development of territories. Electricity is a more environmentally friendly source of energy for households. Environmental pollution at the place of use occurs at a minimum rate. Almost two thirds of electricity generated in Russia is provided by thermal power plants. The latter harm the environment not less, but taking into account the structure of the fuel used and the generation efficiency (not exceeding $34 \%$ ), and more than as a result of gas burning within the household. Placing power plants in remote areas from population centres can be a positive factor in distribution of environmental pressure on the environment. In this case, additional problems arise due to increased costs of power generation in remote areas, and the loss of electricity, reaching 10 percent or more, in transmission over long distances (Bakai E. O., 2017).

The use of natural gas as a source of energy supply has a number of environmental advantages. Approximately 90 percent of natural gas produced is delivered to customers as useful energy. By comparison, only 30 percent of energy converted to electricity reaches consumers. In particular lower gas prices have likely been a moderate contributor to the decrease in American carbon emissions over the last five years (Brehm, 2019). Using natural gas instead of oil or coal produces less chemicals that contribute to greenhouse gases, acid rain, smog, and other harmful forms of pollution. In the long run more natural gas generation should come online changing the way power plants of all fuel types are dispatched (Holladay J. S., LaRiviere J. 2014). Consequently, natural gas is the ultimate alternative fuel of the future.

Gas supply to the region's households can be provided either with pipeline (natural) gas, which mainly consists of methane, or with liquefied petroleum gas (LPG), consisting mainly of a mixture of propane and butane in different proportions. The condition for providing households with pipeline (natural) gas is the need to build trunk and other gas pipelines, and in general - creation of gas distribution network, requiring significant capital investments. Creating a single capital distribution network is not required to supply LPG to household using gas storage tank (gasholder) within the 
household. In this case, the costs of installation of the gasholder and arranging gas pipes within the household are required. The latter equally applies to pipeline gas. In addition, use of gas tanks requires development of roads to ensure delivery of LPG to the users. The road infrastructure is of a more universal nature, relative to the gas distribution network of natural gas, and can be used to solve issues of mobility, health, safety and many others.

Providing households with gas has the advantage of having multiple uses of it. In fact, the presence of gas in the household provides potential for electrification, heating, hot water supply and cooking. That is, it can solve most of the pressing problems of households. Regional authorities, however, should create conditions for availability of additional essential lifelines to ensure sustainability of the energy supply to households. First of all, we are talking about electric power supply, as well as about the options to use local resources (wood, peat etc.) in case of emergencies.

The data posted in table. 1 taken and calculated according to information on tariff rates in force in the Leningrad region for the population of rural areas, directories of conversion factors and current standards for the characteristics of individual fuels. The transfer in euro was carried out based on the average exchange rate of the ruble against the euro for 2019 at 72.4 rubles / EUR. From the tabular data it can be seen that natural gas has the lowest cost per kilowatt-hour of energy. For firewood, when calculating this cost, the coefficient of efficiency of conversion to thermal energy (0.8) was additionally used, since it significantly differs from the efficiency of using other types of energy carriers (0.9-0.95). Given the efficiency of electricity generation within the household, the current supply of electricity to households at the level of comparable electricity prices can be provided only with natural gas.

Economic advantage of natural gas is its price per unit of reproducible energy (Table 1).

Table 1

\section{Cost of energy generated from different types of energy products without taking efficiency of final use into account}

\begin{tabular}{|c|c|c|c|}
\hline Type of fuel & Unit & Unit price & Price EUR•kWh-1 \\
\hline LPG for gasholders (propane-butane mixture 70-30) & EUR・I-1 & 0,27 & 0.04 \\
\hline Pipeline gas (methane assumed) & $\mathrm{EUR} \bullet(\mathrm{m} 3)-1$ & 0,09 & 0.01 \\
\hline Chipped firewood, natural moisture content & $E U R \bullet(m 3)-1$ & 23,00 & 0.02 \\
\hline Electricity & $E U R \bullet k W-1$ & 0,06 & 0.06 \\
\hline
\end{tabular}

Source: author's calculations based on Zemsky G. T. (2016). Flammable Properties of Inorganic and Organic Region Order No. 533-p dated 12/20/2018 "On Setting Tariffs for Electric Energy Supplied to the Population of the Leningrad Region in 2019".

Other types of energy carriers can successfully compete with electricity to solve other problems of life support in terms of current costs (excluding initial capital investments), as noted in the table.

When making decisions about the model of gas supply to households in rural areas, regional authorities should take into account the difference between the price of pipeline gas and LPG, the amount of capital investments in gas distribution networks and the ratio of the service life of these networks to the service life of gasholders. Analysis of operational characteristics shows that the average service life of gas networks up to the time of their overhaul is, according to the current GOST standards, from 25-30 (for metal) to 50 years (for polymer) gas pipelines.

The average actual costs for the construction of gas pipelines are shown in Table 2. 


\begin{abstract}
Calculation of the average cost per kilometre of gas infrastructure development as part of the gas infrastructure development programme of Gazprom Gas Distribution Leningrad Region PJSC for the years 2019-2023 due to special allowances for the tariff for transporting natural gas to users
\end{abstract}

\begin{tabular}{|l|c|c|c|}
\hline \multicolumn{1}{|c|}{ Years } & $\begin{array}{c}\text { Estimated cost, EUR } \\
\text { mIn }\end{array}$ & $\begin{array}{c}\text { Pipeline } \\
\text { length, } \mathbf{~ k m}\end{array}$ & $\begin{array}{c}\text { Unit cost, EUR } \\
\text { mIn॰km-1 }\end{array}$ \\
\hline 2019 & $\begin{array}{c}7.03 \text { including previous } \\
\text { costs incurred (3.16) }\end{array}$ & 80.31 & 0.09 \\
\hline 2020 & 3.85 & 65.58 & 0.06 \\
\hline 2021 & 4.25 & 29.62 & 0.14 \\
\hline 2022 & 4.37 & 40.05 & 0.11 \\
\hline 2023 & 4.51 & 14.00 & 0.32 \\
\hline $2019-2023$ & 24.03 & 230.01 & 0.10 \\
\hline
\end{tabular}

Source: author's calculations based on The Order of the Committee on the Fuel and Energy Complex of the Leningrad Region, 2018

The average cost of laying one kilometre of the gas distribution network in the Leningrad Region as part of one of the gas infrastructure development programmes is planned for 2019-2023 at the level of EUR $102.95 \mathrm{~K} \bullet \mathrm{km}^{-1}$ ( $\mathrm{K}=$ thousand). Fluctuations in the cost of the data are explained by a mismatch the timing of the works and the commissioning of the gas distribution network. Intersettlement gas pipelines are the main construction sites under this programme.

Other gas infrastructure development programmes that focus on distribution gas pipelines within the settlements have an average cost of laying a kilometre of gas distribution infrastructure from EUR $26.67 \mathrm{~K}$ to EUR $53.33 \mathrm{~K} \bullet \mathrm{km}^{-1}$ (The Order of the Committee on the Fuel and Energy Complex of the Leningrad Region, 2018; Decree of the Government of the Leningrad Region, 2018). In general, gas infrastructure development programmes of the region with pipeline gas are funded from several sources: regional and local government funds (in some regions the federal government funds are also involved), funds of Gazprom PJSC and its subsidiaries, as well as through special allowances to the tariff for transporting natural gas to users. The latter is introduced by regional services that control tariffs and represents a mark-up within the framework of gas tariff for individual groups of users (mainly commercial enterprises). Table 3 presents several programmes and plans of the Leningrad Region within which gas infrastructure development of the region is carried out.

The regional authorities of the Leningrad Region incur significant budget expenditures to finance gas infrastructure development programmes. The share of budget expenditures for gas infrastructure development, taking into account the funds of Gazprom PJSC, is at least 35-40\% of the total cost of gas infrastructure development projects in the region. Accounting for government regulation measures largely determines the efficiency of energy supply to rural households (Lukichev P. M., 2016).

Therefore, it is necessary to determine the economic feasibility of conducting pipeline gas to households and to create a method for choosing a gas infrastructure development model between the "pipeline gas" and "gasholder" alternatives. Solving this problem requires comparing the average cost of constructing gas pipelines and other gas infrastructure facilities, taking into account the timing of their operation, with the cost of installing gasholders. The service life of gasholders, judging by the suppliers 'passports, is $20-25$ years, which is comparable to metal gas pipelines and is approximately two times shorter than that of polymer pipes for gas supply networks. The cost of installing a gasholder and the gas distribution system in an average household (rural house) is about 
EUR $4 \mathrm{~K}$. When bringing the gas line to the houses and indoors, it is also required to spend funds in the range of RUR 100-150 K per average rural house.

Consequently, operation of the gas distribution system within the household using gasholder has a comparable service life. The downside is that it is necessary to incur additional costs for supply of pipeline gas in the range of EUR $1.33-2.00 \mathrm{~K}$ for a standard rural house with a floor area of $100-120 \mathrm{~m}^{2}$. The advantage of this solution is that, compared with the pipeline gas option, it does not require construction of a gas supply pipeline. The authors proceed from the assumption that all additional costs of gas infrastructure development with gasholders are borne by the regional authorities, just as it occurs with the costs for construction of intra-settlement gas pipelines under the option of supplying pipeline gas. The government should compensate the households for the difference in prices per unit of energy supplied in the form of LPG and in the form of pipeline gas to ensure equal access of households to the gas infrastructure. This difference is EUR 0.03 per kWh as seen in Table 1. If a standard household of three of its members uses no more than 4,000 litres per year LPG (28161 kWh), then the annual compensation for the cost of LPG use should be EUR 845. Accordingly, for 25 years of operation of a gasholder, undiscounted expenses of the region for compensation, the price of LPG will amount to EUR $21.12 \mathrm{~K}$ per standard household, and taking into account discounting, with a discount rate of $6.25 \%$ (the current key rate of the Central Bank of the Russian Federation) - EUR 10.55 K. Thus, provision of a separate conventional household with gas using gasholders will cost the government no more than EUR $13.9 \mathrm{~K}$ of the present value. At the same time, the costs in the first year of installation will not exceed EUR $4.2 \mathrm{~K}$.

Table 3

\section{Volumes of funds appropriated for various gas infrastructure development programmes of the Leningrad Region}

\begin{tabular}{|c|c|c|c|}
\hline Programme & Years & $\begin{array}{l}\text { Estimated } \\
\text { cost, } \\
\text { EUR mIn } \\
\end{array}$ & Source of funding \\
\hline $\begin{array}{l}\text { Gas infrastructure development programme of } \\
\text { PeterburgGaz LLC for connection of housing and utility } \\
\text { facilities, in the Leningrad Region to gas for the years 2018- } \\
2022\end{array}$ & $2018-2022$ & 11.21 & $\begin{array}{l}\text { Special allowance to } \\
\text { the tariff for } \\
\text { transportation of } \\
\text { natural gas to users }\end{array}$ \\
\hline $\begin{array}{l}\text { Gas infrastructure development programme of Gazprom } \\
\text { Gas Distribution Leningrad Region JSC for the years 2019- } \\
2023\end{array}$ & $2019-2023$ & 24.89 & $\begin{array}{l}\text { Special allowance to } \\
\text { the tariff for } \\
\text { transportation of } \\
\text { natural gas to users }\end{array}$ \\
\hline $\begin{array}{l}\text { Comprehensive development of social and engineering } \\
\text { infrastructure for rural communities, objects of the } \\
\text { subprogramme "Sustainable development of rural territories } \\
\text { of the Leningrad Region" of the governmental programme } \\
\text { of the Leningrad Region "Agricultural development of the } \\
\text { Leningrad Region" }\end{array}$ & 2014-2024 & 18.44 & $\begin{array}{l}\text { Regional and local } \\
\text { government funds }\end{array}$ \\
\hline $\begin{array}{l}\text { Subprogramme "Gas infrastructure development of the } \\
\text { Leningrad Region" of the governmental programme of the } \\
\text { Leningrad Region "Ensuring sustainable operation and } \\
\text { development of utilities and engineering infrastructure and } \\
\text { improvement of energy efficiency in the Leningrad Region" }\end{array}$ & $2018-2024$ & 95.36 & $\begin{array}{l}\text { Regional and local } \\
\text { government funds }\end{array}$ \\
\hline
\end{tabular}

\section{Research results and discussion}

As a result, it becomes possible to assess feasibility of connecting sparsely populated communities and communities remote from gas mains to pipeline gas. For example, if we take the cost of laying a gas pipeline for EUR $64.36 \mathrm{~K} / \mathrm{km}$, then, with the current introductory gas pipeline with a total length of even $1 \mathrm{~km}$, it is not expedient from the point of view of spending government funds for 
programmes of providing gas to households if it provides less than 5 standard households with gas. Financing a gas supply scheme using gasholders by the region would be economically feasible in this case.

LPG market is more competitive than the market of pipeline gas in Russia. While the pipeline gas is provided, in fact, by one company, LPG can be produced and delivered by a much wider number of suppliers from gas and petrol industry. Therefore, the region's active policy of maintaining competition in the LPG market can mitigate risks of reducing the economic affordability of gas supply for households.

\section{Conclusions, proposals, recommendations}

1) Natural gas and LPG have a high environmental safety in comparison to other types of fuel and allow organizing simultaneous provision of most of utility services to households. Ensuring sustainability of the delivery of public services to households, in addition to gas supply, also requires supplying electricity, and, in some cases, stimulating organization of energy supply using local resources.

2) The main factors for the region to choose a gas connection scheme for individual groups of households ("pipeline gas" or "gasholders") are: difference in tariffs for pipeline gas and LPG, cost of capital expenditures for building gas supply infrastructure, remoteness and density of households in the territory, lifetime of gas supply systems, structure of sources of funding for gas infrastructure development programmes, model to ensure the level of competition in the LPG market, capacities of the region in providing long-term guarantees for price subsidies and LPG.

3) Preparation of documents for territorial planning and location of households, especially in the framework of the settled farm model of settlements, requires not only gas infrastructure development plans for pipeline gas and measures to regulate LPG prices, but also subsidization of costs for supplying individual households with gas using individual gasholders and communal gasholders in remote areas with dense arrangement of households.

\section{Bibliography}

1. Oficial'nyj sajt PAO "Gazprom». (PJSC Gazprom.) [13.03.2019]. Retrieved: http://www.gazprom.ru/press/news/2019/february/article476017 /; Utverzhdena pyatiletnyaya programma razvitiya gazosnabzheniya i gazifikacii Leningradskoj oblasti. (The Five-Year Program for the Development of Gas Supply and Gasification of the Leningrad Region has been approved). [online] [13.03.2019]. Retrieved: http://www.gazprom.ru/press/news/2016/september/article283981/.

2. Wang, Z., Zhang, B., Yin, J., Zhang, Y. (2011). Determinants and Policy Implication of household Electricity Saving Behaviour: Evidence from Beijing China. Energy Policy, vol. 39, pp. 3550-3557.

3. Swan, G., Ugursal, V. (2008). Modeling of End-use Energy Consumption in the Residential Sector: A Review of Modeling Techniques. Renewable and Sustainable Energy Reviews, vol. 13, pp. 1819-1835.

4. Danlami, A.H., Islam, R., Applanaidu, S.D. (2015). An Analysis of the Determinants of Households' Energy Choice: A Search for Conceptual Framework. International Journal of Energy Economics and Policy, vol. 5(1), pp. 197-205.

5. Chekmarev O.P., Konev P.A. (2018). Ustojchivoe razvitie: podhody k opredeleniyu (Sustainable Development: Approaches to the Definition). Proceedings of the International Academy of Agricultural Education, vol. 38, pp. 109-113.

6. Aksyutin O.E., Ishkov A.G., Romanov K.V., Pystina N.B., Akopova G.S., Kosolapova E.V. (2017). Ekologicheskaya effektivnost' proizvodstva i ispol'zovaniya prirodnogo gaza na osnove ocenki polnogo zhiznennogo cikla. (Ecological Efficiency of Production and Use of Natural Gas Based on the Assessment of the Full Life Cycle). Scientific and Technical Collection. Vesti gas science, vol. 5(33), pp. 3-11.

7. Bakai E.O. (2017) Ekonomiko-statisticheskij analiz poter' pri peredache elektroenergii po vysokovol'tnym provodam $\vee$ Rossii (Economic-Statistical Analysis of Losses in the Transmission of Electricity through Highvoltage Wires in Russia). Bulletin of the South Ural State University. Series: Economics and Management, vol. 11 , no. 4, pp. 117-125.

8. Brehm, P. (2019). Natural Gas Prices, Electric Generation Investment, and Greenhouse Gas Emissions. Resource and Energy Economics, vol. 58, pp. 101-116. 
9. Holladay J.S., LaRiviere J. (2014). The Impact of Cheap Natural Gas on Marginal Emissions from Electricity Generation and Implications for Energy Policy. Working Paper. Retrieved: http://web.utk.edu/ jlarivi1/docs/HL_gas.pdf.

10. Komitet po tarifam i cenovoj politike Leningradskoj oblasti Prikaz №533-p ot 20.12.2018 «Ob ustanovlenii tarifov na elektricheskuyu energiyu, postavlyaemuyu naseleniyu Leningradskoj oblasti v $2019 \mathrm{~g}$.» (Tariffs and Pricing Policy Committee of the Leningrad Region Order No. 533-p dated 12/20/2018 "On Setting Tariffs for Electric Energy Supplied to the Population of the Leningrad Region in 2019").

11. Lukichev P.M. (2016). Regulatory Challenges for the Russian High North During the Current Economic Crisis. Management in the High North Young researches' contribution. Collection of essays, Volume 2. Edited by Bourmistrov A., Dybtsyna E., Nazarova N. - Nord universitet, Utredning nr. 9, Bodo, p. 189-198.

12. Postanovlenie Pravitel'stva Leningradskoj oblasti ot 20.09.2018 N 348 "O vnesenii izmeneniya v postanovlenie Pravitel'stva Leningradskoj oblasti ot 9 marta 2016 goda N 54 "Ob utverzhdenii Perechnya ob"ektov podprogrammy "Ustojchivoe razvitie sel'skih territorij Leningradskoj oblasti" gosudarstvennoj programmy Leningradskoj oblasti "Razvitie sel'skogo hozyajstva Leningradskoj oblasti" i o vnesenii izmenenij v postanovlenie Pravitel'stva Leningradskoj oblasti ot 29 dekabrya 2012 goda N 463 "O gosudarstvennoj programme Leningradskoj oblasti "Razvitie sel'skogo hozyajstva Leningradskoj oblasti". (Decree of the Government of the Leningrad Region of 20.09.2018 N 348 "On Amendments to the Decree of the Government of the Leningrad Region of March 9, 2016 No. 54" On Approving the List of Objects of the Subprogram "Sustainable Development of Rural Areas of the Leningrad Region" of the State Program of the Leningrad Region "Agricultural Development of the Leningrad Region "and on Amending the Decree of the Government of the Leningrad Region of December 29, 2012 No. 463" On the State Program of the Leningrad Region "Development of Agriculture Sector of the Leningrad Region").

13. Postanovlenie Pravitel'stva Leningradskoj oblasti ot 20.09.2018 N 342 "O vnesenii izmeneniya v postanovlenie Pravitel'stva Leningradskoj oblasti ot 18 dekabrya 2015 goda N 482 "Ob utverzhdenii Perechnya ob"ektov podprogrammy "Gazifikaciya Leningradskoj oblasti" gosudarstvennoj programmy Leningradskoj oblasti "Obespechenie ustojchivogo funkcionirovaniya i razvitiya kommunal'noj i inzhenernoj infrastruktury i povyshenie energoeffektivnosti $v$ Leningradskoj oblasti". (Resolution of the Government of the Leningrad Region of September 20, 2018 N 342 "On Amendment to the Resolution of the Government of the Leningrad Region of December 18, 2015 No. 482" On Approval of the List of Sub-Program Facilities "Gasification of the Leningrad Region" of the State Program of the Leningrad Region " Infrastructure and Energy Efficiency in the Leningrad region").

14. Rasporyazhenie komiteta po toplivno-energeticheskomu kompleksu Leningradskoj oblasti ot 04.09.2018 N 57 "Ob utverzhdenii programmy gazifikacii OOO "PeterburgGaz" ob"ektov zhilishchno-kommunal'nogo hozyajstva, raspolozhennyh na territorii Leningradskoj oblasti na 2018-2022 gody i o priznanii utrativshimi silu nekotoryh rasporyazhenij komiteta po toplivno-energeticheskomu kompleksu Leningradskoj oblasti". (The Order of the Committee on the Fuel and Energy Complex of the Leningrad Region of 09/04/2018 N 57 "On the Approval of the Gasification Program of PeterburgGaz LLC of Housing and Communal Facilities Located in the Leningrad Region for 2018-2022 and on the Recognition of Certain Orders of the Fuel Committee -Energy Complex of the Leningrad Region").

15. Rasporyazhenie komiteta po toplivno-energeticheskomu kompleksu Leningradskoj oblasti ot 24.12.2018 N 95 "Ob utverzhdenii programmy gazifikacii AO "Gazprom gazoraspredlenie Leningradskaya oblast'" na 2019-2023 gody". (The Order of the Committee on the Fuel and Energy Complex of the Leningrad Region of 12/24/2018 N 95 "On Approval of the Gasification Program of Gazprom Gas Distribution Leningrad Region for 2019-2023").

16.Zemskij G. T. (2016). Ogneopasnye svojstva neorganicheskih i organicheskih materialov: spravochnik (Flammable Properties of Inorganic and Organic Materials: a Reference Dook) Moskva: VNIIPO. p. 337. 